\title{
MORTALITY FOR CHRONIC-DEGENERATIVE DISEASES IN TUSCANY: ECOLOGICAL STUDY COMPARING NEIGHBORING AREAS WITH SUBSTANTIAL DIFFERENCES IN ENVIRONMENTAL POLLUTION
}

\section{CLAUDIO MARABOTTI ${ }^{1,2}$, PAOLO PIAGGI ${ }^{3,4}$, PAOLO SCARSI ${ }^{5}$, ELIO VENTURINII ${ }^{1}$, ROMINA CECCHI ${ }^{1}$, and ALESSANDRO PINGITORE ${ }^{2}$}

${ }^{1}$ Bassa Val di Cecina Hospital, Cecina (LI), Italy

Cardiovascular and Coronary Care Unit

${ }^{2}$ National Research Council (CNR), Pisa, Italy

Institute of Clinical Physiology

${ }^{3}$ National Institutes of Health, Phoenix, Arizona, USA

Phoenix Epidemiology and Clinical Research Branch, National Institute of Diabetes and Digestive and Kidney Diseases

${ }^{4}$ University of Pisa, Pisa, Italy

Department of Endocrinology and Metabolism

${ }^{5}$ National Research Council (CNR), Pisa, Italy

Institute of Geosciences and Earth Resources

\begin{abstract}
Objectives: Environmental pollution is associated with morbidity and mortality for chronic-degenerative diseases. Recent data points out a relationship between proximity to industrial plants and mortality due to neoplasms. The aim of this study has been to compare mortality due to chronic-degenerative diseases in the area of Tuscany (Bassa Val di Cecina), Italy, characterized by the presence of 2 neighboring municipalities similar in terms of size but with substantial differences in industrial activities: Rosignano (the site of chemical, energy production and waste processing industries) and Cecina (with no polluting activity). Material and Methods: Standardized mortality rates for the 2001-2010 decade were calculated; the data of the whole Tuscany was assumed as reference. Environmental levels of pollutants were obtained by databases of the Environmental Protection Agency of Tuscany Region (Agenzia Regionale per la Protezione Ambientale della Toscana-ARPAT). Maximum tolerated pollutant levels set by national laws were assumed as reference. Results: In the whole Bassa Val di Cecina, significantly elevated standardized mortality rates due to mesothelioma, ischemic heart diseases, cerebrovascular diseases and Alzheimer and other degenerative diseases of nervous system were observed. In the municipality of Rosignano, a significant excess of mortality for all these groups of diseases was confirmed. On the contrary, the municipality of Cecina showed only significantly higher mortality rates for ischemic heart diseases. Elevated levels of heavy metals
\end{abstract}

Received: March 20, 2016. Accepted: June 28, 2016.

Corresponding author: C. Marabotti, Bassa Val di Cecina Hospital, Cardiovascular and Coronary Care Unit, via Montanara 1, 57023 Cecina (LI), Italy (e-mail: c.marabotti@alice.it). 
in sea water and of particulate matter which contains particles of diameter $\leq 10 \mathrm{~mm}\left(\mathrm{PM}_{10}\right)$ and ozone in air were detected in Rosignano. Conclusions: This study shows an excess of mortality for chronic-degenerative diseases in the area with elevated concentration of polluting factories. Proximity to industrial plants seems to represent a risk factor for those diseases. Int J Occup Med Environ Health 2017;30(4):641-653

Key words:

Heavy metals, Particulate matters, Environmental pollution, Mesothelioma, Ischemic heart disease, Neurologic degenerative diseases

\section{INTRODUCTION}

The relationship between ambient pollution and morbidity and mortality due to neoplasms and chronic respiratory diseases has been demonstrated by a large number of epidemiological observations [1,2]. More recently, an association between environmental pollution (particularly due to heavy metals contamination of water) and cardiovascular diseases has also been reported [3]. The residential proximity to potentially polluting industries is a known powerful risk factor for mortality due to pollution-related diseases [4]. In particular, workers living in contaminated areas (i.e., in close proximity to polluting industrial activities) may have both professional exposure during working hours and environmental exposure while off duty [5]. On the contrary, commuting workers, travelling on a daily basis from their residence (somewhat far from polluting industrial activities) to their workplace, share only professional exposure with resident workers [5]. The district named Bassa Val di Cecina, including 10 municipalities with approx. 82000 inhabitants, is situated on the coast of Tuscany, Italy, a few kilometers south of the towns of Leghorn and Pisa (Figure 1).

The particularity of this district is the presence, just in the middle of the area, of 2 neighboring mid-sized municipalities (where majority of population is concentrated), similar in terms of the number of inhabitants (about 30000 each) but with considerably different economic background. In the municipality of Rosignano Marittimo an important industrial site is located, including several factories, dealing with chemical production, disposal and recovery of hazardous and urban wastes, energy production. About a half of the inhabitants live in
Rosignano Solvay, situated in close proximity of the industrial site (Figure 2). In 1999, the World Health Organization (WHO) identified the community of Rosignano Solvay as a "priority pollution hotspot in the Mediterranean" [6]. On the other hand, Cecina (12 km south) has an economy prevailingly based on tourism, agriculture and trade. An epidemiological evaluation of pollution-related mortality in this area seems particularly interesting, since inhabitants may be differently exposed to pollutants: from the maximum, represented by people who are both working and living in proximity of polluting factories, to the minimum, represented by people who are neither living near, nor working in polluting industries. Both commuting industrial workers and non-industrial workers living in the proximity of polluting activities may represent intermediate levels of environmental pollution risk.

A retrospective evaluation of both mortality rates due to chronic-degenerative diseases and environmental exposure to pollutants in this area has therefore been designed. The aims of this study have been:

- to evaluate the possible excess in mortality due to potentially pollution-related diseases in the whole Bassa Val di Cecina and in the 2 main municipalities of the area (Rosignano Marittimo and Cecina) with different industrial impact,

- to investigate the potential links between the possible excess in mortality rates and environmental release and detection of pollutants,

- to discuss the pathophysiological mechanisms linking environment pollution to the diseases responsible for the excess in mortality. 


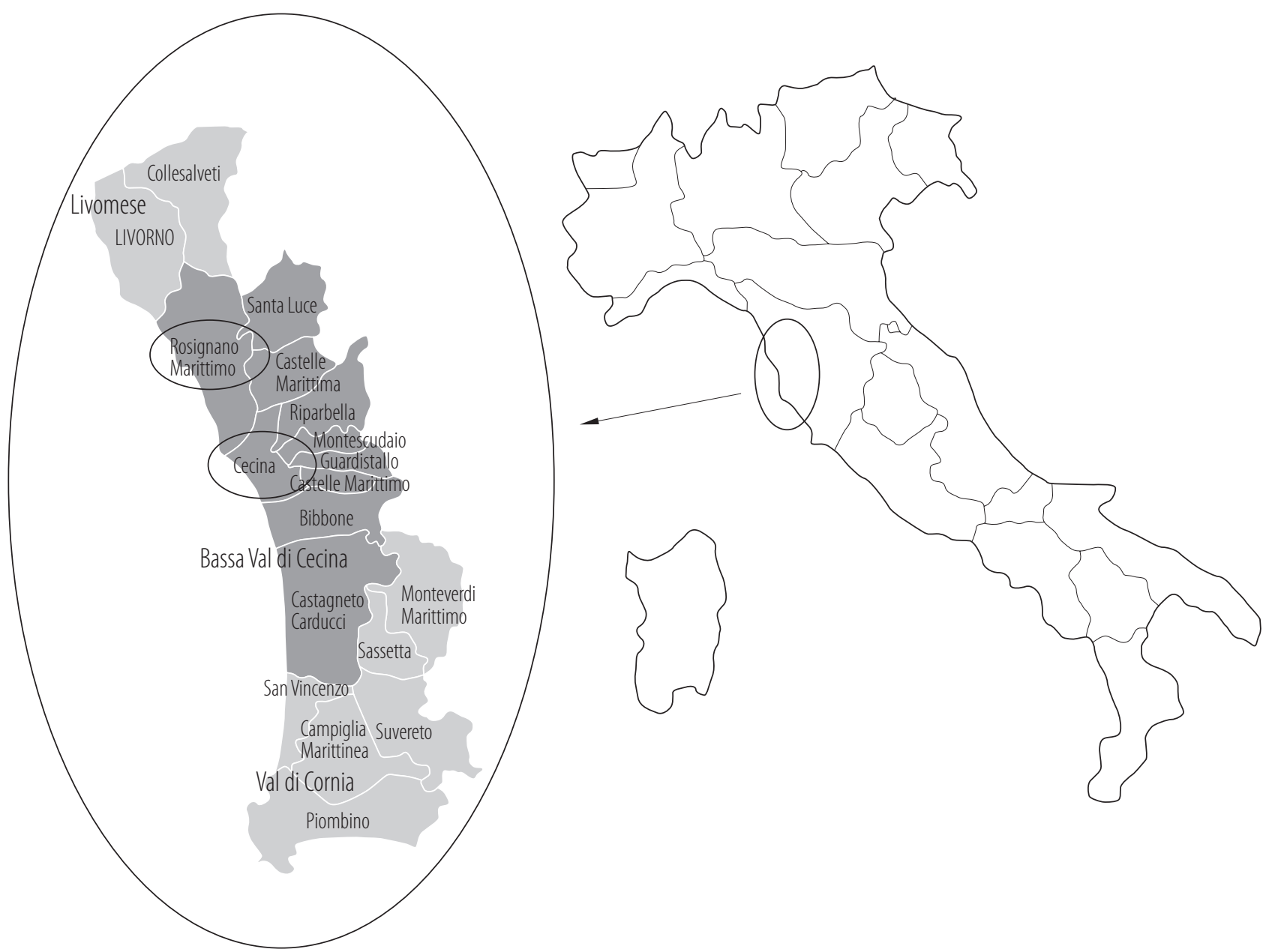

- Bassa Val di Cecina area

$\bigcirc$ - the 2 largest municipalities in the area of Bassa Val di Cecina: Rosignano Marittimo (with high degree of industrial concentration) and Cecina (with very low level of industrial concentration)

Fig. 1. Studied area of Italy in the study of association of environmental pollution with morbidity and mortality for chronic-degenerative diseases

\section{MATRIAL AND METHODS}

\section{Demographic and mortality data source}

Mortality rates for the years 2001 to 2010 were obtained by files elaborated by the Institute for Oncological Study and Prevention (Istituto per lo Studio e la Prevenzione Oncologica - ISPO) for the area of Bassa Val di Cecina and for the municipalities of Rosignano Marittimo and Cecina. Standardized mortality rates in the whole area and in the 2 largest municipalities were compared to the corresponding rates of Tuscany as a whole, assumed as a reference.
All-cause mortality, mortality for chronic-degenerative diseases and mortality for respiratory diseases potentially pollution-related were evaluated. In particular, the following International Statistical Classification of Diseases and Related Health Problems, 10th revision (ICD-10) codes were investigated: malignant neoplasms (as a whole, $\mathrm{C} 00$ $\mathrm{C} 75$, and the single codes of each neoplastic disease), diabetes mellitus (E10-E14), ischemic heart diseases (I20I25), acute myocardial infarction (I21), other forms of ischemic heart disease (I20, I22-I25), cerebrovascular 


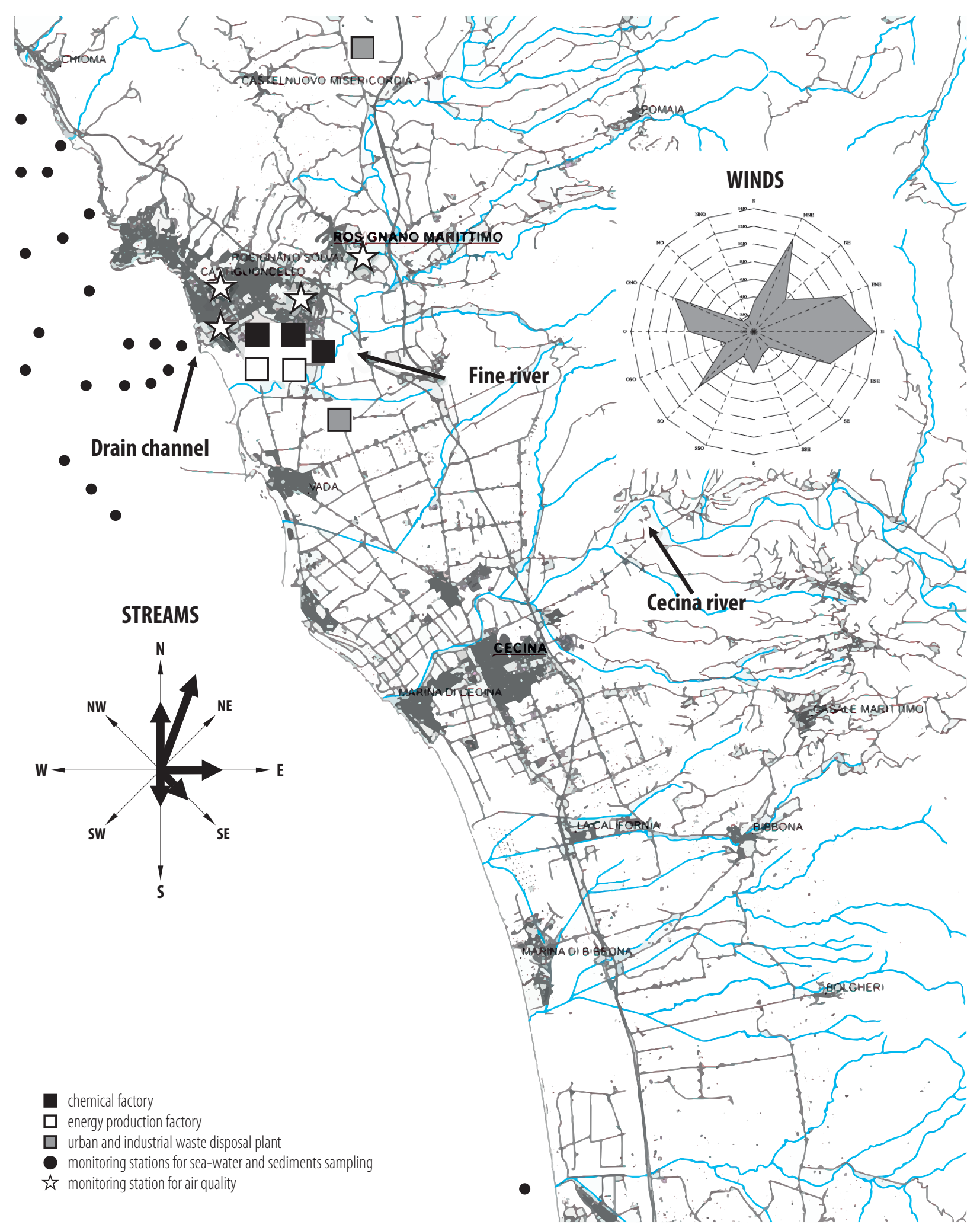

Fig. 2. Studied area - Bassa Val di Cecina, Italy 
diseases (I60-I69), hypertensive diseases (I10-I15), diseases of arteries, arterioles and capillaries (I70-I78), Alzheimer and other degenerative diseases of nervous system (G30-G32), other forms of dementia (F00-F03), motor neuron disease (G12.2), multiple sclerosis (G35), chronic lower respiratory diseases (J40-J47), lung diseases due to external agents (J60-J70).

An indicator estimating the proportion of workers professionally exposed to pollutants (in the whole area and in the 2 largest municipalities) was obtained by relating the number of subjects employed in industrial activities with the number of inhabitants. Demographic data was collected by 2011 Population Census [7]. The number of industrial workers was obtained by 2011 Industry Services Census [8]. Both datasets were elaborated by the National Institute for Statistics (Istituto Superiore di Statistica - ISTAT).

\section{Pollutants release and detection}

Data about the presence of polluting industrial activities and about the amount of pollutants release (in air, water and soil) was collected from the European Pollution Release and Transfer Register (E-PRTR) [9]. Data was available for the years 2001, 2004 and from 2005 to 2013. Since development of pollution-related diseases requires time, emission of pollutants in the same decade of mortality analysis may be considered as only a general indicator of pollutants exposure.

Data about air and water contamination was collected from databases of the Environmental Protection Agency of Tuscany Region (Agenzia Regionale per la Protezione Ambientale della Toscana - ARPAT) [10-13] and reports of the National Research Council (Consiglio Nazionale delle Ricerche - CNR), Institutes of Geosciences and Earth Resources and of Biophysics (Pisa, Italy) [14-17]. Air pollution was evaluated, in Rosignano Marittimo, by 4 permanent monitoring stations [10]. Two of them were located at the border of industrial plants, neighboring to the residential area; the other 2 were "background" stations, one placed in the urban area, the other - on the top of a hill, a few kilometers away from both the city center and industrial plants. Data was available for the years 2002-2010. Levels of particulate matter (which contains particles of diameter $\leq 10 \mathrm{~mm}\left(\mathrm{PM}_{10}\right)$ and diameter $\leq 2.5 \mathrm{~mm}\left(\mathrm{PM}_{2.5}\right)$ ), ozone, nitrogen dioxide $\left(\mathrm{NO}_{2}\right)$, nitrogen oxides $\left(\mathrm{NO}_{\mathrm{x}}\right)$, sulfur dioxide $\left(\mathrm{SO}_{2}\right)$ and carbon monoxide (CO) were monitored. It is relevant to note that $\mathrm{PM}_{2.5}$ were monitored only by one of the "background" stations, far from both urban area and industrial plants.

Due to the low potential exposition to ambient pollution, no permanent air monitoring system is active in Cecina. In the years 2013-2014, a mobile monitoring station was placed within the residential area of Cecina [11]. Even if this period does not correspond to that of the study, that data could be useful to have a comparison with data obtained in the neighboring municipality of Rosignano Marittimo, with higher industrial exposure.

Quality of air was evaluated according to the criteria of the Directive 2008/50/EC of the European Parliament and of the Council of 21 May 2008 on ambient air quality and cleaner air for Europe [18].

Pollution of the sea in front of Rosignano Marittimo was evaluated by a system of monitoring stations located in the area overlooking the drain channel of the only chemical factory declaring pollutants release to water [12]. Water and sediment sampling was extended northward, according to the direction of prevailing streams. The only southward monitoring station is situated about $12 \mathrm{~km}$ south of Cecina. Both water and sediment analyses were available for the years 2002 to 2010. Moreover, in the years 2004 and 2005, a study of metals bioaccumulation in water-filtering animals (mussels - Mytilus galloprovincialis) was performed in the shoals in front of Rosignano Marittimo [13].

Pollution of groundwater was evaluated during sampling campaigns performed between 1995 and 2008, in the area 
of Bassa Val di Cecina. Sampling of water and sediments from both the Cecina River and from wells located in the coastal area were analyzed [14-17]. Pollutants bioaccumulation was also assessed in fresh water fish caught in the Cecina River [14].

Quality of the sea and groundwater was evaluated according to criteria settled by Italian national law (DM 260/2010) [19].

\section{Statistical analysis}

The $\mathrm{Chi}^{2}$ test was used for comparing the mortality rates for each ICD-10 code between each area and the whole Tuscany region. For diseases resulting in the excess of mortality, a post-hoc analysis to evaluate the statistical significance of differences between the 2 areas with different pollution level was performed.

The 95\% confidence interval for the mortality rates was calculated and rates were compared by the z-test. Analyses were performed in the whole population and then stratified by gender. No correction was made for multiple tests because all analyses were preplanned and of independent interest.

Data is presented as count and percentage. Analyses were performed using SPSS (v. 21, IBM Corp., USA).

\section{RESULTS}

\section{Geographic and demographic data}

Most of Bassa Val di Cecina is occupied by a coastal plan crossed by 2 rivers, Cecina and Fine, flowing near the 2 largest communities (Cecina and Rosignano Solvay, respectively). The Fine River is $22 \mathrm{~km}$ long; its course is all inside the Bassa Val di Cecina area and no industrial plant is situated along its course. The Cecina River is $73 \mathrm{~km}$ long; most of its course is outside the Bassa Val di Cecina territory. A geothermal power plant and a chemical factory are located in the upper course of the river.

The area of Bassa Val di Cecina is inhabited by 82023 people (39 404 males, 42619 females); 1986 subjects were

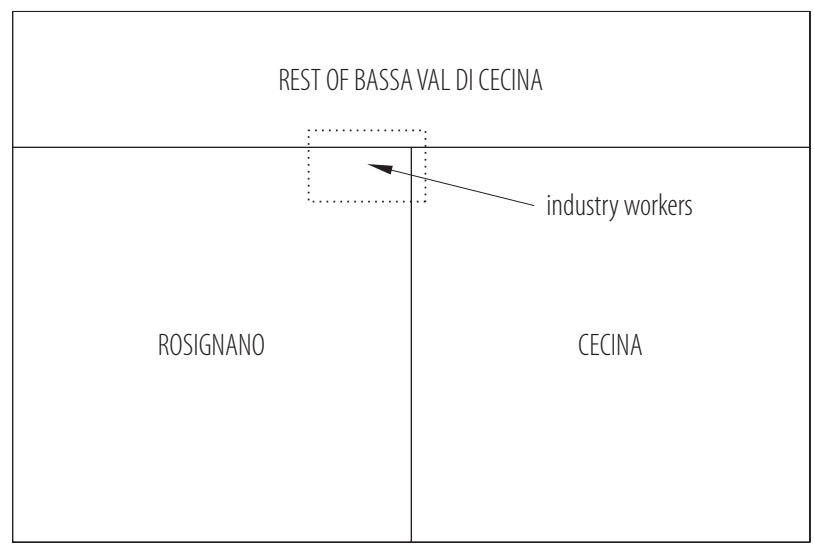

Areas are proportional to the number of inhabitants.

Fig 3. Inhabitants and industry workers in the area of Bassa Val di Cecina, Italy

industrial workers $(2.42 \%)$. As previously mentioned, the majority of population (73.12\%) was concentrated in the 2 largest municipalities: Rosignano Marittimo had 32494 inhabitants (15 759 males, 16735 females), Cecina had 28864 inhabitants (13 292 males, 15572 females). The number of industrial workers was, respectively, 1199 (3.76\% of municipality population) and 285 (1.01\% of municipality population) (Figure 3).

\section{Mortality rates}

Total mortality rates in the studied areas were not significantly different, as compared to regional data.

When compared to the Tuscany region, the area of Bassa Val di Cecina showed significantly higher standardized mortality rates due to mesothelioma (C45), ischemic heart diseases (I20-I25), other forms of ischemic heart disease (I20, I22-I25), cerebrovascular diseases (I60-I69) and Alzheimer and other degenerative diseases of nervous system (G30-G31) (Table 1). In the municipality of Rosignano Marittimo, a significant excess of mortality for all these groups of diseases was confirmed. On the contrary, the municipality of Cecina showed only significantly higher mortality rates for ischemic heart diseases (I20-I25) and other forms of ischemic heart disease (I20, I22-I25). 


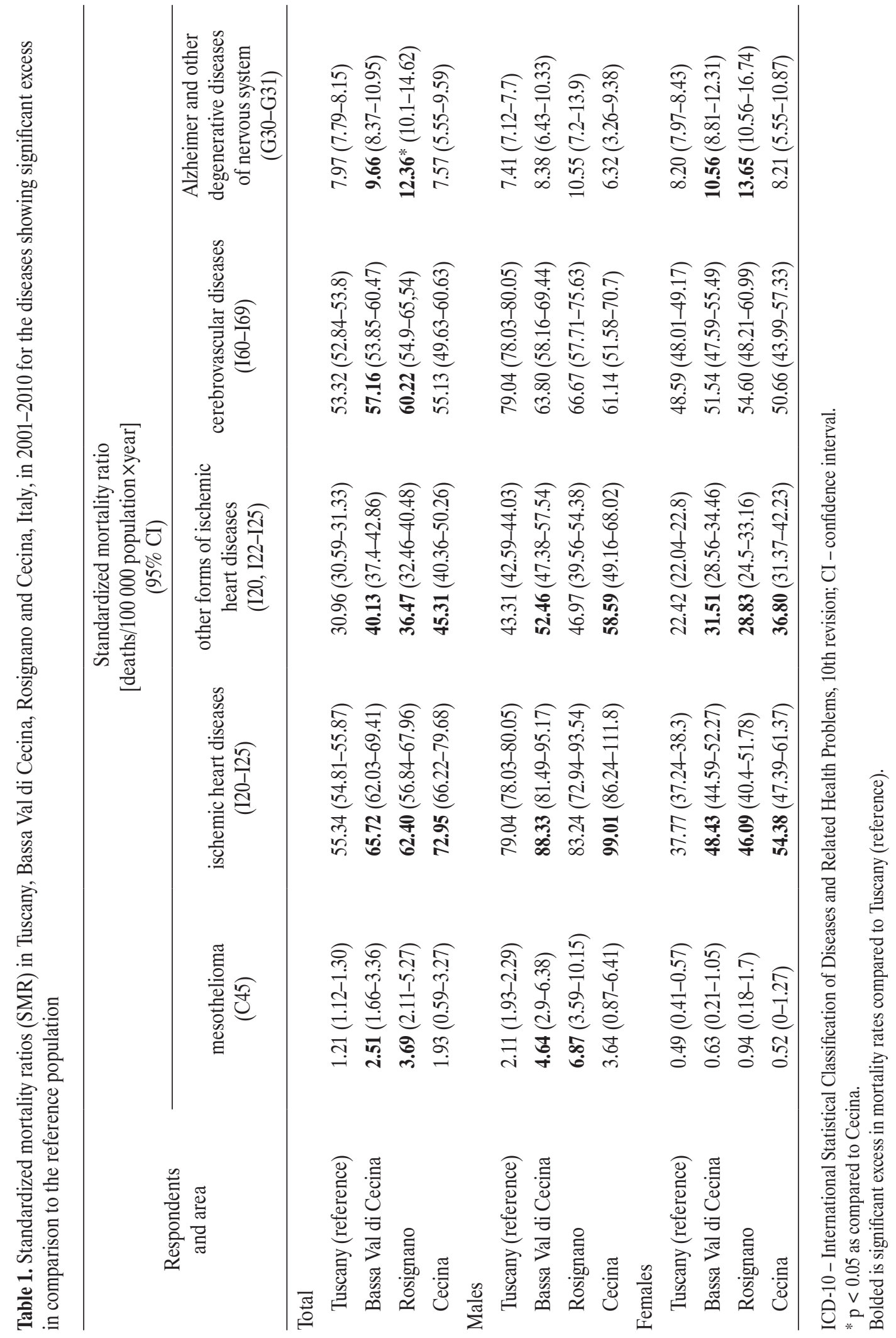


The analysis of data disaggregated by gender showed, in Rosignano Marittimo, a significant excess in mortality for mesothelioma in males and for ischemic heart diseases, other forms of ischemic heart disease and Alzheimer disease in females. In the municipality of Cecina, a significant excess of mortality for ischemic heart diseases and other forms of ischemic heart disease was observed in both genders (Table 1).

\section{Polluting activities}

Seven polluting industrial activities are included in E-PRTR database for the area of Bassa Val di Cecina: 3 chemical production factories, 2 plants for energy production from fossil fuels (natural gas), 1 plant for disposal and recovery of industrial and hazardous waste, 1 landfill for urban waste. All polluting sites are situated in the municipality of Rosignano Marittimo: 6 of them in the close proximity of the urban settlement, while the remaining one (the urban waste landfill) is situated in a valley $10 \mathrm{~km}$ away from the urban community.

\section{Pollutants release}

Mean yearly pollutants releases in the municipality of Rosignano Marittimo (as obtained by E-PRTR database) are reported in the Table 2.

Release to air: chemical factories released, yearly, large amounts of carbon monoxide and carbon dioxide, ammonia, non-methane volatile organic compounds, hydrochlorofluorocarbons and nitrogen oxides. For 3 years (2001, 2004 and 2007) one chemical plant declared the release of $84 \mathrm{~kg}, 48 \mathrm{~kg}$ and $16 \mathrm{~kg}$ of mercury to atmosphere, respectively.

Table 2. Yearly release of pollutants in Rosignano Marittimo (Italy), 2001-2010, as reported in the European Pollutant Release and Transfer Register (E-PRTR) [9]

\begin{tabular}{lccc}
\hline \multicolumn{1}{c}{ Substance } & \multicolumn{2}{c}{ Substance release into environment } \\
& \multicolumn{2}{c}{$(\mathrm{M} \pm \mathrm{SD})$} & soil \\
\cline { 2 - 4 } & air & water & 0 \\
\hline Carbon monoxide $(\mathrm{CO})\left[\mathrm{t} / 10^{3}\right]$ & $209.83 \pm 212.01$ & 0 & 0 \\
Carbon dioxide $\left(\mathrm{CO}_{2}\right)\left[\mathrm{t} / 10^{3}\right]$ & $257.11 \pm 83.41$ & 0 & 0 \\
Ammonia $\left(\mathrm{NH}_{3}\right)[\mathrm{t}]$ & $9.31 \pm 10.15$ & 0 & 0 \\
Hydrochlorofluorocarbons $(\mathrm{HCFCs})[\mathrm{t}]$ & $733.56 \pm 208.41$ & 0 & 0 \\
Nitrogen oxides $\left(\mathrm{NO}_{\mathrm{x}}\right)[\mathrm{t}]$ & $25.32 \pm 14.92$ & 0 & 0 \\
Nitrogen oxide $(\mathrm{NO})[\mathrm{t}]$ & $197.78 \pm 118.21$ & 0 & 0 \\
Non-methane volatile organic compounds (NMVOC) $[\mathrm{t}]$ & 0 & $1.94 \pm 0.56$ & 0 \\
Arsenic $(\mathrm{As})[\mathrm{t}]$ & $16.44 \pm 29.96$ & $88.09 \pm 49.07$ & 0 \\
Mercury $(\mathrm{Hg})[\mathrm{kg}]$ & 0 & $108.44 \pm 49.66$ & 0 \\
Cadmium $(\mathrm{Cd})[\mathrm{kg}]$ & 0 & $4.17 \pm 1.89$ & 0 \\
Lead $(\mathrm{Pb})[\mathrm{t}]$ & 0 & $2.82 \pm 1.17$ & 0 \\
Chromium $(\mathrm{Cr})[\mathrm{t}]$ & 0 & $1.79 \pm 0.83$ & 0 \\
Nickel $(\mathrm{Ni})[\mathrm{t}]$ & 0 & $2.21 \pm 0.82$ & 0 \\
Copper $(\mathrm{Cu})[\mathrm{t}]$ & 0 & $12.97 \pm 4.02$ & 0 \\
Zinc $(\mathrm{Zn})[\mathrm{t}]$ & & & 0 \\
\hline
\end{tabular}

M - mean; SD - standard deviation. 
Urban waste landfill released large amounts of methane to air on the annual basis. Electric power plants released carbon dioxide, nitrous oxide and nitrogen oxides.

Release to water: 1 out of the 3 chemical plants declared releases of pollutants to water, particularly concerning heavy and transitional metals. Yearly releases (mean $(\mathrm{M}) \pm$ standard deviation (SD)) of potentially dangerous metals in the evaluated period are reported in the Table 2.

Release of pollutants occurs directly into the sea, through a drainage sewer, in close proximity to the residential area. Release to soil: no industrial plant declared pollutant release to soil.

\section{Environmental pollutants tracing}

Air pollution: when compared to European parameters for ambient air quality, high levels of $\mathrm{PM}_{10}$ (from 2003 to 2006) and ozone (from 2007 on), expressed both as average annual levels and as absolute number of exceedances, were detected in Rosignano Marittimo, in the 2 monitoring stations placed at the borders between industrial and urban area [10].

No exceeding was reported during the temporary monitoring of air pollution performed in Cecina in 2013-2014 [11]. Water pollution: the analysis of the seawater column showed, in front of Rosignano, levels of Mercury higher than the limits settled by national regulations [12]. Similar values were found in all the sampling stations northward (in the direction of prevailing currents) as well as in the one situated southward [12].

The sediment analysis in the area overlooking the industrial plants in Rosignano showed levels of mercury, cadmium, arsenic, chromium and nickel higher than law-determined limits [12]. High levels of metals in sediments were also found in northward sampling sites, according to the direction of prevailing sea currents [12]. In 1982, a core sampling study performed on sediments 1.5 nautical miles offshore the drain channel showed highly elevated concentrations of mercury at a depth approximately corresponding to the period 1940-1970, when mercury cell electrolysis was used in chemical industries of the area [12]. High level of nickel in sediments was the only abnormal parameter found in the monitoring station located South [12]. High levels of chromium, arsenic and nickel were found in mussels gathered in front of Rosignano Marittimo [13]. As far as groundwater pollution is concerned, high levels of chromium (of natural origin) [14], organic nitrates (due to the use of organic fertilizers) [17], boron and mercury $[15,16]$ (both released by chemical and geothermal plants situated in the upper course of the river) were found in water and sediments of the Cecina River basin. Elevated organic mercury concentrations were also documented in several fish species caught in the river (particularly in eels - Anguilla anguilla) [15].

Soil pollution: since industrial plants do not release pollutants to soil, no data has been collected. Partial data is available only for asbestos contamination; in 2007, the Environmental Protection Agency of Tuscany Region (ARPAT) took a census of the sites containing asbestos in Tuscany. Unfortunately, the resulting database is limited to public buildings and industrial plants (no information is provided about the presence of asbestos in private buildings) and is only a list of sites, with no indication of the amount of asbestos in each site [20].

\section{DISCUSSION}

This retrospective study reports a significant excess in mortality due to ischemic heart diseases, cerebrovascular disease, Alzheimer disease and mesothelioma in the area of Tuscany coast with a high concentration of industrial plants. In the same area, reports of E-PRTR pointed out the release of considerable amount of pollutants both in seawater (mostly metals) and in air (nitrous and nitrogen oxides, ammonia, carbon monoxide and dioxide). Environmental monitoring showed critical levels of several pollutants: $\mathrm{PM}_{10}$ and ozone in air, mercury and other metals in seawater and sediments. All pollutants but mercury 
(both in the sea and freshwater) were more elevated in the industrialized area of Rosignano Marittimo.

Several mechanisms could support a possible pathogenetic link between environmental pollution and the increased mortality rates for these illnesses.

On the one hand, the wide use of asbestos in industry, as a component of tools for thermal insulation, is a wellknown strong risk factor for mesothelioma, so that this type of pleural cancer has been recognized as an accurate indicator of asbestos contamination [21]. On the other hand, pollution due to transitional and heavy metals (released in large amounts in seawater by chemical plants situated in Rosignano Marittimo, and objectively detected both in water and sediments) could contribute to explain the increased mortality from both Alzheimer disease and cardiovascular diseases.

The hypothesis that metal environment contamination might represent a common risk factor for this heterogeneous group of diseases deserves a few comments.

Strong epidemiological studies support a causal link between chronic environmental exposure to xenobiotic metals (arsenic, lead, cadmium and mercury) and cardiovascular morbidity [22,23]. All heavy metals may reduce antioxidant cellular pool, increasing the intracellular concentration of reactive oxygen species and promoting lipid peroxidation and both cell membrane and DNA damages. Moreover, some heavy metals may also affect traditional cardiovascular risk factors. For instance, chronic lead overload (both evaluated by its blood and bone levels) is associated to arterial hypertension and dyslipidemia [22]. As a result, an increase in vascular inflammation and endothelial damage markers [24] and early carotid atherosclerotic changes [25] have been reported in chronically exposed subjects to heavy metals.

A possible role of air-released pollutants may also be supposed. Actually, previous studies showed that cardiovascular morbidity and mortality are related to both particulate matter and ozone [26,27]; high levels of both these air pollutants were detected in Rosignano Marittimo. Moreover, in one cohort study, Norwegian men exposed to nitrogen oxides showed significantly higher mortality for ischemic heart disease [28].

A causal link between metal pollution and Alzheimer disease has been hypothesized many years ago, since aluminum deposits were detected in neurons of affected patients showing neurofibrillary tangle [29]. Moreover, prospective epidemiological studies showed that chronic aluminum exposure was associated with a high risk of cognitive impairment [30]. Similar evidences have been reported also for other metals, largely released in the area of the study. An altered cerebral zinc homeostasis is associated with generation of extracellular $\beta$-amyloid plaques and neuronal neurofibrillary tangles [31], while an increase in non-ceruloplasmin-bound copper has been reported both in animal models and in humans affected by Alzheimer disease [32]. Finally, both groundwater arsenic levels and chronic low-level cumulative exposure to lead (as assessed by bone lead content) appears to be associated with cognitive decline humans [33,34].

A further, although indirect, possible link between environmental pollution and Alzheimer disease could reside in the effect of the above reported circulatory abnormalities, potentially responsible of vascular dementia.

A few differences have been observed in mortality rates reported in the 2 largest municipalities of the studied district. In particular, an increased mortality for mesothelioma, Alzheimer disease and cerebrovascular diseases were observed only in Rosignano Marittimo, while both municipalities shared an increased mortality due to ischemic heart disease. A causal link between proximity to industrial plants and mesothelioma seems confirmed by the presented data, showing increased mortality for mesothelioma only in the industrialized area of Rosignano Marittimo. In this area, almost $4 \%$ of residents is employed in industrial activities and may represent a subset at the highest risk of contracting an asbestos-related illness. As known, mesothelioma may develop after a long latency after 
asbestos exposure; in a previous study, the median latency time from exposure to disease onset was 37 years (range: 19-68 years) [35]. Since the safety procedure in handling asbestos has been progressively implemented in the last 5 decades, it is conceivable that, in the past, some amount of asbestos might have leaked out from industrial plants, contaminating the surrounding urban area. A careful investigation of each case of mesothelioma, to identify the possible cases arising in subjects with no professional exposure to asbestos, seems thus strongly advised.

Mortality for both Alzheimer disease and cerebrovascular diseases is significantly higher in the municipality of Rosignano Marittimo, suggesting a possible pathogenetic role of pollutants in these diseases. On the contrary, the observation of an increased mortality due to ischemic heart diseases also in the area of Cecina, with far less industrial activities, may be expression of a generalized heavy metals environmental contamination. This hypothesis may be supported by the elevated levels of mercury documented also in the area of Cecina, and by the elevated levels of metals found in biological specimens of the sea and freshwater organisms, suggesting the penetration of pollutants in food chain.

\section{CONCLUSIONS}

This study retrospectively documents, in an area with elevated levels of air and seawater pollutants, an excess of mortality for several chronic-degenerative diseases. No direct evaluation of individual exposure to polluting agents has been performed and it is not possible to establish a causal link between environmental pollution and increased mortality. Alternative causes could therefore contribute to (or even totally explain) the reported differences in mortality for cardiovascular and neurodegenerative diseases. In particular, differences in traditional risk factors for chronic-degenerative illnesses (i.e., smoke, obesity, arterial hypertension, diabetes and dyslipidemia) or in socio-economic deprivation levels could account for the observed mortality differences. Even if these topics should be scrutinized in future studies, significant differences in socio-economic status (as expressed by the Social and Material Vulnerability Index), calculated by ISTAT [36] have not been observed between the 2 municipalities of Rosignano Marittimo and Cecina.

\section{ACKNOWLEDGMENTS}

Authors wish to thank Antonio Lombardi and Maria Gloria Marinari (Prevention Department, AUSL 6, Leghorn, Italy) and Salvatore de Masi (Epidemiology Unit, Ospedale Pediatrico Meyer, Florence, Italy) for their support in collecting epidemiological data.

Authors particularly appreciated the invaluable contribution of Fabrizio Bianchi (Environmental Epidemiology, CNR Institute of Clinical Physiology, Pisa, Italy) to the interpretation and discussion of results.

\section{REFERENCES}

1. Katsouyanni K, Pershagen G. Ambient air pollution exposure and cancer. Cancer Causes Control. 1997;8(3):284-91, https:// doi.org/10.1023/A:1018492818416.

2. Sunyer J. Urban air pollution and chronic obstructive pulmonary disease: A review. Eur Respir J. 2001;17(5):1024-33, https://doi.org/10.1183/09031936.01.17510240.

3. Miller KA, Siscovick DS, Sheppard L, Shepherd K, Sullivan JH, Anderson GL, et al. Long-term exposure to air pollution and incidence of cardiovascular events in women. N Engl J Med. 2007;356(5):447-58, https://doi.org/10.1056/ NEJMoa054409.

4. Fernàndez-Navarro $\mathrm{P}$, Garcìa-Perez J, Ramis R, Boldo E, Lòpez-Abente G. Proximity to mining industry and cancer mortality. Sci Total Environ. 2012;435-36:66-73, https://doi. org/10.1016/j.scitotenv.2012.07.019.

5. Signorino G, Pasetto R, Gatto E, Mucciardi M, La Rocca M, Mudu P. Gravity models to classify commuting vs. resident workers. An application to the analysis of residential risk in a contaminated area. Int J Health Geogr. 2011;10:11, https:// doi.org/10.1186/1476-072X-10-11. 
6. United Nations Environment Programme, World Health Organization. Identification of Priority Pollution Hot Spots and Sensitive Areas in the Mediterranean. MAP Technical Reports Series No. 124. Athens: The Programme; 1999.

7. National Institute for Statistics [Internet]. Rome: The Institute; 2011a [cited 2016 Feb 19]. [Population and residences census]. Available from: http://dati-censimentopopolazione. istat.it/?lang=it. Italian.

8. National Institute for Statistics [Internet]. Rome: The Institute 2011b [cited 2016 Feb 19]. [Industry and services census]. Available from: http://dati-censimentoindustriaeservizi. istat.it/?lang=it. Italian.

9. European Anvironment Agency [Internet]. Copenhagen: The Agency [cited 2016 Feb 19]. European Pollution Release and Tratnsfer Register. Available from: http://prtr. ec.europa.eu/\#/home.

10. Agenzia regionale per la protezione ambientale della Toscana [Internet]. Firenze: Agenzia; 2010 [cited 2016 Feb 19]. [Report on air quality - Leghorn, 2010]. Available from: http://www.arpat.toscana.it/documentazione/report/relazione-qualita-aria-livorno-2010.zip. Italian.

11. Agenzia regionale per la protezione ambientale della Toscana. [Quality of air monitoring campaign performed by a mobile laboratory between June 2013 to July 2014] [Internet]. Firenze: Agenzia; 2014 [cited 2016 Feb 19]. Available from: http://www.provincia.livorno.it/fileadmin/Ambiente/ campagnadimonitoraggio2013-2014.pdf. Italian.

12. Agenzia regionale per la protezione ambientale della Toscana [Internet]. Firenze: Agenzia; 2014 [cited 2016 Feb 19]. [Quality of coastal sea water overlooking Solvay drain channel in Rosignano (LI)]. Available from: http://www.arpat. toscana.it/documentazione/catalogo-pubblicazioni-arpat/ qualita-delle-acque-marino-costiere-prospicienti-lo-scaricosolvay-di-rosignano-li. Italian.

13. Agenzia regionale per la protezione ambientale della Toscana. [MONIQUA project: Monitoring of sea water and marine environment quality. Sardinia, Corsica, Tuscany] [Internet]. Firenze: Agenzia; 2005-2010 [cited 2016
Feb 19]. Available from: http://www.arpat.toscana.it/attivita/arpat-2005-2010/allegati/CON-Mare-2-Moniqua. zip/?searchterm=MONIQUA. Italian.

14. Lelli M, Grassi S, Amadori M, Franceschini F. Natural $\mathrm{Cr}(\mathrm{VI})$ contamination of groundwater in the Cecina coastal area and its inner sectors (Tuscany, Italy). Environ Earth Sci. 2014;71:3907-19, https://doi.org/10.1007/s12665-013-2776-2.

15. Scerbo R, Ristori T, Stefanini B, de Ranieri S, Barghigiani C. Mercury assessment and evaluation of its impact on fish in the Cecina river basin (Tuscany, Italy). Environ Pollut. 2005;135(1):179-86, https://doi.org/10.1016/j.envpol. 2004.07.027.

16. Pennisi M, Gonfiantini R, Grassi S, Squarci P. The utilization of boron and strontium isotopes forthe assessment of boron contamination of the Cecina River alluvial aquifer (centralwestern Tuscany, Italy). Appl Geochem. 2006;21:643-55, https://doi.org/10.1016/j.apgeochem.2005.11.005.

17. Grassi S, Cortecci G, Squarci P. Groundwater resource degradation in coastal plains: The example of the Cecina area (Tuscany - Central Italy). Appl Geochem. 2007;22:2273-89, https://doi.org/10.1016/j.apgeochem.2007.04.025.

18. Directive 2008/50/EC of the European Parliament and of the Council of 21 May 2008 on ambient air quality and cleaner air for Europe. Off J L 152, p. 1-44 (June 11, 2008). Available from: http://eur-lex.europa.eu/legal-content/EN/ TXT/?uri=CELEX:32008L0050.

19. Gazzetta Ufficiale della Repubblica Italiana [Internet]. Rome: Gazzetta; 2011 [cited 2016 Feb 19]. [Decreto 8 novembre 2010 n. 260]. Available from: http:/www.gazzettaufficiale.it/eli/id/2011/02/07/011G0035/sg. Italian.

20. Agenzia regionale per la protezione ambientale della Toscana [Internet]. Firenze: Agenzia; 2007 [cited 2016 Feb 19]. [Asbestos mapping in Tuscany]. Available from: http:// www.arpat.toscana.it/temi-ambientali/amianto/mappatura. Italian.

21. Micheli A, Capocaccia R, Martinez C, Mugno E, Coebergh JW, Baili P, et al. Cancer control in Europe: A proposed set of European cancer health indicators. Eur J Pub- 
lic Health. 2003;13:116-8, https://doi.org/10.1093/eurpub/13. suppl_3.116.

22. Solenkova NV, Newman JD, Berger JS, Thurston G, Hochman JS, Lamas GA. Metal pollutants and cardiovascular disease: Mechanisms and consequences of exposure. Am Heart J. 2014;168(6):812-22, https://doi.org/10.1016/ j.ahj.2014.07.007.

23. Moon K, Guallar E, Navas-Acien A. Arsenic exposure and cardiovascular disease: An updated systematic review. Curr Atheroscler Rep. 2012;14(6):542-55, https://doi.org/10.1007/ s11883-012-0280-x.

24. Wu F, Jasmine F, Kibriya MG, Liu M, Wójcik O, Parvez F, et al. Association between arsenic exposure from drinking water and plasma levels of cardiovascular markers. Am J Epidemiol. 2012;175(12):1252-61, https://doi.org/10.1093/ aje/kwr464.

25. Wang CH, Jeng JS, Yip PK, Chen CL, Hsu LI, Hsueh YM, et al. Biological gradient between long-term arsenic exposure and carotid atherosclerosis. Circulation. 2002;105(15): 1804-9, https://doi.org/10.1161/01.CIR.0000015862.64816.B2.

26. Forastiere F, Stafoggia M, Picciotto S, Bellander T, D'Ippoliti D, Lanki T, et al. A case-crossover analysis of outof-hospital coronary deaths and air pollution in Rome, Italy. Am J Respir Crit Care Med. 2005;172(12):1549-55, https://doi.org/10.1164/rccm.200412-1726OC.

27. Raza A, Bellander T, Bero-Bedada G, Dahlquist M, Hollenberg J, Jonsson M, et al. Short-term effects of air pollution on out-of-hospital cardiac arrest in Stockholm. Eur Heart J. 2014;35(13):861-8, https://doi.org/10.1093/eurheartj/eht489.

28. Nafstad P, Håheim LL, Wisløff T, Gram F, Oftedal B, Holme I, et al. Urban air pollution and mortality in a cohort of Norwegian men. Environ Health Perspect. 2004;112(5): 610-5, https://doi.org/10.1289/ehp.6684.

29. Crapper DR, Krishnan SS, Dalton AJ. Brain aluminium distribution in Alzheimer's disease and experimental neurofibrillary degeneration. Science. 1973;180:511-23, https://doi.org/10.1126/science.180.4085.511.

30. Rondeau V, Jacqmin-Gadda H, Commenges D, Helmer C, Dartigues JF. Aluminium and silica in drinking water and the risk of Alzheimer's disease or cognitive decline: Findings from 15-years follow-up of the PAQUID cohort. Am J Epidemiol. 2009;169:489-96, https://doi.org/10.1093/aje/ kwn348.

31. Tzyska-Czochara M, Grzywacz A, Gdula-Argasinska J, Librowsky T, Wilinski B, Opoka W. The role of Zinc in the pathogenesis and treatment of central nervous system (CNS) diseases. Implications of Zinc homeostasis for proper CNS function. Acta Pol Pharm. 2014;71(3):369-77.

32. Pal A, Siotto M, Prasad R, Squitti R. Towards a unified vision of copper involvement in Alzheimer's disease: A review connecting basic, experimental and clinical research. J Alzeheimers Dis. 2015;44:343-54, https://doi.org/10.3233/JAD141194.

33. Edwards M, Johnson L, Mauer C, Barber R, Hall J, O'Bryant S. Regional specific groundwater arsenic levels and neuropsychological functioning: A cross-sectional study. Int J Environ Health Res. 2014;24:546-57, https://doi.org/ 10.1080/09603123.2014.883591.

34. Bandeen-Roche K, Glass TA, Bolla KI, Todd AC, Schwartz BS. Cumulative lead dose and cognitive function in older adults. Epidemiology. 2009;20(6):831-9, https://doi. org/10.1097/EDE.0b013e3181b5f100.

35. Mowé G, Gylseth B, Hartvelt F, Skaug V. Occupational asbestos exposure, lung-fiber concentration and latency time in malignant mesothelioma. Scand J Work Health. 1984;10:293-8, https://doi.org/10.5271/sjweh.2326.

36. National Institute for Statistics [Internet]. Rome: The Institute 2011c [cited 2016 Feb 19]. [A selection of indicators for every Italian municipality]. Available from: http://ottomilacensus.istat.it. Italian.

This work is available in Open Access model and licensed under a Creative Commons Attribution-NonCommercial 3.0 Poland License - http://creativecommons.org/ licenses/by-nc/3.0/pl/deed.en. 